\title{
Methods of Research in the Investigation and Interpretation of Architecture and the Built Environment Guest Editorial
}

\author{
Myra Nan Rosenfeld
}

Volume 16, numéro 2, 1989

Études sur l'architecture et son environnement

Studies on Architecture and its Environment

URI : https://id.erudit.org/iderudit/1073141ar

DOI : https://doi.org/10.7202/1073141ar

Aller au sommaire du numéro

\section{Éditeur(s)}

UAAC-AAUC (University Art Association of Canada | Association d'art des universités du Canada)

\section{ISSN}

0315-9906 (imprimé)

1918-4778 (numérique)

\section{Découvrir la revue}

\section{Citer ce document}

Rosenfeld, M. N. (1989). Methods of Research in the Investigation and Interpretation of Architecture and the Built Environment: Guest Editorial. RACAR : Revue d'art canadienne / Canadian Art Review, 16(2), 115-117. https://doi.org/10.7202/1073141ar
Résumé de l'article

Le Centre Canadien d'Architecture fut établi en 1979 par Phyllis Lambert afin de promouvoir des connaissances approfondies de l'architecture, de son histoire, et de son environnement chez le grand public, les architectes, et les chercheurs. Lorsque les deux rédacteurs de RACAR, Clifford Brown et Chandler Kirwin, avaient proposé de consacrer un numéro de RACAR au Centre Canadien d'Architecture, le directeur et les conservateurs ont décidé qu'il serait intéressant de démontrer à travers l'analyse des collections du CCA et de son édifice, les méthodes de recherche employées dans l'étude et l'interprétation d'oeuvres conservées par un musée d'architecture. Les conservateurs de musée ont une tâche assez ardue de sauvegarder, d'étudier et d'interpréter ces oeuvres, ce qui rend nécessaire une étroite collaboration avec les bibliothécaires, les restaurateurs, les archivistes et les photographes. Les conservateurs de musée doivent posséder une connaissance non seulement de l'art du connaisseur mais aussi de plusieurs disciplines intellectuelles afin de poursuivre la recherche. Récemment les historiens de l'art ont été préoccupés tout particulièrement par les problèmes de méthodologie. Le conservateur de musée ne peut pas se permettre d'employer une seule méthodologie. La méthode de recherche choisie doit être déterminée par l'objet d'art lui-même. Par contre, plusieurs méthodes et disciplines intellectuelles doivent être utilisées ensembles par le conservateur. Dans les articles qui suivent, le lecteur trouvera une démonstration de ces différentes méthodes de recherche employées par les conservateurs d'un musée d'architecture. Les oeuvres discutées dans ce numéro de RACAR seront exposées au CCA pendant l'automne 1990. Nous tenons à remercier tous les membres du CCA qui ont collaboré à ce numéro de RACAR ainsi que Clifford Brown et Chandler Kirwin qui nous ont apporté une aide précieuse.
Tous droits réservés @ UAAC-AAUC (University Art Association of Canada | Association d'art des universités du Canada), 1989
Ce document est protégé par la loi sur le droit d'auteur. L'utilisation des services d'Érudit (y compris la reproduction) est assujettie à sa politique d'utilisation que vous pouvez consulter en ligne.

https://apropos.erudit.org/fr/usagers/politique-dutilisation/ 


\title{
Methods of Research in the Investigation and Interpretation of Architecture and the Built Environment
}

\author{
MYRA NAN ROSENFELD \\ Research Curator, Canadian Centre for Architecture
}

Guest Editor

\section{RÉSLMÉ}

Lc Centre Canadien d'Architecturc fut ćtabli en 1979 par Phyllis Lambert afin de promouvoir des connaissances approfondies de l'architecture, de son histoire, et de son environnement che $\%$ le grand public, les architcctes, et les chercheurs. Lorsque les deux rédacteurs de RaCAR, Clifford Brown el Chandler Kirwin, avaient proposé de consacrer un numéro de RaCiar au Centre Cianadien d'Architecture, le directeur et les conservateurs ont décidé qu'il serait intéressant de démontrer à travers l'analyse des collections du c.CA ct de son édifice, les méthodes de recherche employćcs dans l'étude et l'intcrprétation d'ocuvres conservées par un muséc d'architecture. Les conscrvatcurs de musée ont une tâchc assez. arduc de sauvcgarder, d'étudier et d'interpréter ces oeuvres, ce qui rend nécessairc une ćtroitc collaboration avec les bibliothécaires, les restaurateurs, les archivistes et les photographcs. I ces conscrvateurs de muséc doivent posséder une connaissance non sculc- ment de l'art du connaisseur mais aussi de plusieurs disciplines intellectuelles afin de poursuivre la recherchc. Récemment les historiens de l'art ont ćté préoccupés tout particulièrement par les problèmes de méthodologic. Ie conscrvatcur de musée ne pcut pas se permettre d'employer unc seule méthodologic. I a méthode de recherche choisic doit ĉtre détcrminéc par l'objet d'art lui-même. Par contre, plusieurs méthodes et disciplines intcllectuclles doivent ĉtrc utilisées ensembles par le conscrvatcur. Dans les articles qui suivent, le lecteur trouvera une démonstration de ces différentes méthodes de recherche cmployées par les conscrvatcurs d'un musće d'architecture. Les ocuvres discutćcs dans ce numéro de raciar scront exposées au cca pendant l'automne 1990. Nous tenons à remercier tous les membres du ccia qui ont collaborć à ce numéro de RACAR ainsi que Clifford Brown et Chandler Kirwin qui nous ont apporté une aide précieuse.
The Canadian Centre for Architecture was founded in 1979 by Phyllis Lambert in order to further a greater understanding of architecture, its history, and the built environment. Its mission is eloquently described in "An Appreciation" in this issue of RAC.AR by Adolf K. Placzek who was involved in the early stages of the ccA's creation. Phyllis Lambert explains the relationship between the aims of the cCA and its collections policy in "Director's Choice: Report on Selected Acquisitions, 1985-89."

When the editors of RACAR proposed devoting an entire issue of RACAR to the Canadian Centre for Architecture, the curators of the c.cA suggested using an analysis of a select group of books, engravings, drawings, and photographs as the basis for a demonstration of the methods employed in the identification and interpretation of works collected by museums devoted to architecture. In addition to the staff members of the cca, two guest curators, Isabelle Gournay and Barbara Shapiro, were invited to write about drawings in the c.c.'s collection on which they had carried out extensive research. Furthermore, Helen Searing, the author of a recent book on American art museums, was asked to contribute an article on the c.ca building. ${ }^{1}$

The cca collects drawings, prints, books, photographs, models, and archival material which reveal the creative process of the architect as well

I New American Art Museums (Berkeley, 1982). 
as the economic, political, social, and cultural context of buildings and their environment. The curators who have a mandate to care for, research, and interpret these objects face a complex task, one which they carry out in collaboration with librarians, conservators, archivists, and photographers. In addition to the art of connoisseurship, museum curators must apply a knowledge of several different intellectual disciplines in their research. Recently, there has been a particular preoccupation with the problems of methodology in art and architectural history as well as with the establishment of new approaches. ${ }^{2}$ The use of a single methodological approach is not appropriate for the muscum curator, since this strategy imposes a straitjacket onto the objects. For the curator, the method chosen to solve the problems posed by the object has to be determined by the object itsclf. A curator must often use different methodologies together. These include stylistic analysis, historical and archival research, investigation of the social, economic, and political context of a building or architect's life, analysis of technological innovations, and textual and literary interpretation.

Because the cca collects different media devoted to a single subject, it is possible to carry out rescarch on issues which have very broad cul1.ural implications. Between 1974 and 1986, Phyllis Iambert, and subsequently the cCA, collected drawings, prints, and books by Jacques Androuct Du Cerceau and his workshop. When the I ibrary acquired in 1987 the engraved model book of the Grands lemples et habitations fortifiés with the signatures of its sixteenth- and early seventeenthcentury owners, I was able to discover, as I discuss in this issue of RACAR, which members of French socicty actually used Du Cerceau's books and how the relatively new invention of printing changed the way in which ideas were transmitted from designer to mason, architect, and patron in the Renaissance.

Buildings are often used by rulers to propagandize their dynastic aspirations. David Booth explains how an album of drawings presented by the architects Louis-Pierre Baltard and JeanBaptiste Rondelet to a competition organized by Napoléon I was related to contemporary political events. Napolćon I's desire to transform the church of the Madeleine in Paris into a Temple of Glory in honour of his armies was the consequence of a decision taken on the battlefront in 1806 . This proposed, but never executed, Temple of Glory

2 Sec the very illuminating discussion on methodological problems in recent publications on architecture by Marvin Trachtenberg, "Some Recent (Observations on Recent Architectural History," Art Bulletin, I.xx, no. 2 (1988), 208-41. alluded (o) Napoléon I's desire to be ruler of all of liurope and Russia in addition to limpereur des français. Ironically, the former position cluded him.

The cca's collections of photographs, prints, and rare books can be used to study how information on architecture has been interpreted and transmitted through written texts and visual images. In the nineteenth century, photography of architecture was of ten considered to be merely a transparent window on the world. Critics in our time consider photography to be a medium akin to drawing and printing through which the photographer can interpret the world by using different techniques. David Harris analyzes how Alexander Henderson chose certain points of view and particular scenes for his album of photographs of the snowstorms and floods which occurred in Montréal in 1869. Rather than providing us with an exact record of these natural disasters, Henderson's album presents an interpretation of an event which reflects the social and economic conditions of the profession of the photographer in the nincteenth century.

Architects, like photographers, use different methods to represent buildings in drawings and models. Investigation of these methods is essential to determine the architect's conception of architecture. A large archive of the drawings and written records of one architect and his of fice permits the historian to follow the design process for a single building from inception to construction. Isabelle Gournay, in her analysis of the 1,300 drawings and blueprints for the Université de Montréal, was able to discover how Ernest Cormier adapted the methods of draftsmanship he had learned at the Ecole des Beaux-Arts in Paris to the conditions of North American architectural practice. Furthermore, through an examination of the drawings executed by the members of his office, Isabelle (rournay was able to determine that Cormier had a close working relationship with his assistants.

In their project to transform the church of the Madeleine into a Temple of Glory for the armies of Xapolcon I, Baltard and Rondelet chose the Roman Temple of Mars Lltor as their model. On the other hand, Lloyd Wright had no built precedents to study for the 1929 compctition to design a concrete airport sponsored by the Lehigh Portland Cement Company of Allentown, Pennsylvania. Howard Shubert, in his analysis of a series of conceptual and finished presentation drawings, explores how Lloyd Wright evolved a new building type which incorporated clements of urban planning in response to the recent invention of the airplane. 
When Le Corbusier's drawing for the unesco building in Paris was acquired at auction in 1988, its great importance was not apparent to the compilers of the auction catalogue who had given it a most summary description. In preliminary research carried out before the auction, Barbara Shapiro discovered that it was the only known drawing by Le Corbusier for the unesco building. Subsequently, through a careful study of Le Corbusier's buildings as well as of documents in the Fondation Le Corbusier in Paris, Barbara Shapiro was able to define the significance of Le Corbusier's contribution to the final design of the UNESCO building which was carried out by the team of Bernard Zehrfuss, Marcel Breuer, and Pier Luigi Nervi. In addition, she has shown how contemporary political events and personal intrigues played a role in the complex design process.

This issue of RACAR ends with Helen Searing's art historical analysis of the new building designed by Peter Rose to house the Canadian Centre for Architecture. Phyllis Lambert was both client and consulting architect. The cc:A's building not only expresses the mission and functions of the institution, but also makes a statement about the art and history of architecture. Helen Searing considers the building within the tradition of earlier muscums of art and architecture. She also discusses the two inaugural exhibitions, one of which is about the building itself, in relationship to Peter
Rose's design for the building and to the aims of the cca. In dealing with contemporary monuments, the architectural historian has a special task which involves weighing the information and insights provided by the living actors in the drama, the client and the architect, against his or her own interpretation.

The preparation of this issue of RACAR has been truly an institution-wide collaborative effort. Apart from the authors, I would like to thank Murray Waddington, Head Librarian, Rosemary Haddad, Douwe Ernsting, Pierre Boisvert, and Peter Trépanier, also of the Library, Gilles Lessard of the Office of the Registrar, Alain Laforest and Michel Boulet of Photographic Services, Louise Dćsy of the Photographs Collection, Robert Desaulniers and Robert Fortier of the Archives Collection, Guy Doré, Associate Director of Finance and Administration, and Nicholas ()lsberg, Head of Collections. Special thanks goes to Andrea Arthurs of the Research Department for her devoted assistance and numerous editorial suggestions, and to Clifford Brown and Chandler Kirwin for their gracious invitation to the CCA and for their assistance in bringing this project to fruition. I could not have accomplished my task without the gencrous support and encouragement of Clifford Brown. The works discussed in this issue of RACAR will be exhibited at the CCA during the autumn of 1990.

Cientre Canadien d'Archilecturel Canadian Cientre for Architecture 1920, rue Baile

Montréal, suébec H3H2S6 